\title{
PROCEEDINGS OF THE BIOCHEMICAL SOCIETY
}

The Annual General Meeting of the Biochemical Society was held in the Department of Biochemistry, University College, Gower Street, London, W.C. 1, on Friday, 18 April 1958, starting at 10.45 a.m.; the Meeting continued on Saturday, 19 April 1958, starting at 10.30 a.m. The following papers were read:

\section{COMMUNICATIONS}

Absorption of Gystine and Gysteine from Rat Small Intestine. By M. W. NeIL. (Department of Biochemistry, London Hospital Medical College, Turner Street, London, E. 1)

Studies have been made in this laboratory on the absorption of cystine and cysteine from the small intestine of the rat using both an in situ lumen perfusion technique (Neil, 1957) and the everted sac technique of Wilson \& Wiseman (1954).

Using the in situ preparation the rates of absorption for both amino acids were found to increase approximately linearly with increasing initial concentration in the perfusion fluid. The upper concentration limit for cystine was fixed by its solubility in physiological saline at $\mathrm{pH} \mathrm{7.4}$. Supersaturated solutions which were stable during the experimental period could not be prepared. When the perfusion fluid contained cysteine it was equilibrated with $95 \% \mathrm{~N}_{2}, 5 \% \mathrm{CO}_{2}$ and not with $95 \% \mathrm{O}_{2}, 5 \% \mathrm{CO}_{2}$. The rates of absorption from different regions of the rat small intestine varied for both amino acids in the order: duodenum $>$ jejunum $>$ ileum. The D-isomers were absorbed from the duodenum at significantly lower rates than the L-isomers. 2:4-Dinitrophenol (DNP) added to the perfusion fluid $\left(3 \times 10^{-4} \mathrm{M}\right)$ after a control period had no effect on the rates of absorption of the $\mathrm{L}$-isomers. It is interesting to note that DNP also had no effect on the rate of absorption of D-glucose from rat jejunum in this preparation, whereas phlorrhizin $\left(10^{-3} \mathrm{M}\right)$ caused practically complete inhibition. The absorption of L-methionine was similarly unaffected by the presence of DNP. Controls on the preparation were carried out by routine determinations of tissue potassium and water and by histological examination. The intracellular potassium concentration (about $430 \mathrm{~m}$-equiv./kg. fat-free dry tissue) was well maintained, but the water content rose from about 78.5 to $81.8 \%$ (calculated on a fat-free basis) during $2-4 \mathrm{hr}$. perfusion periods.

Using the everted sac technique, control experiments showed a decrease in intracellular potassium and an increase in the water content during $1 \mathrm{hr}$. incubation. Further experiments demonstrated that these changes occurred in the first $10 \mathrm{~min}$. of incubation, and that a new steady state was rapidly established in which the potassium and water contents of the tissue were about $350 \mathrm{~m}$ equiv. $/ \mathrm{kg}$. and $84 \%$ respectively. The serosal/ mucosal amino acid concentration ratios for jejunal sacs rose during $1 \mathrm{hr}$. incubation from $1 \cdot 0$ to $1 \cdot 1$ (L-methionine) and $2 \cdot 9$ (L-cystine) but fell to 0.89 for D-cystine. DNP $\left(3 \times 10^{-4} \mathrm{M}\right)$ caused catastrophic damage to the sacs, the potassium contents of both the whole tissue and the mucosal cells alone rapidly fell to about $50 \%$ of normal. The effects of DNP on absorption processes in such preparations are probably unspecific in view of the gross generalized damage caused.

It seems probable from these studies that both L-cystine and L-cysteine are actively absorbed from the rat small intestine, possibly by a common mechanism.

\section{REFERENCES}

Neil, M. W. (1957). Biochem. J. 65, 41 P.

Wilson, T. H. \& Wiseman, G. (1954). J. Physiol. 123, 116.

Partial Acid Hydrolysis of the Cell-wall of Micrococcus lysodeikticus. By H. R. Perkins and H. J. Rogers. (National Institute for Medical Research, Mill Hill, London, N.W. 7)

Micrococcus lysodeikticus (strain NCTC 2665) was grown by incubation overnight at $30^{\circ}$ of nutrient agar surface cultures, harvested, and washed twice with water. The cell-walls were then prepared by the method of Cummins \& Harris (1956). The final product was dried at $105^{\circ}$ overnight. By acid hydrolysis and chromatographic examination it was found to contain alanine $(20 \%)$, glutamic acid $(13 \%)$, glycine $(11 \%)$, lysine $(20 \%)$, glucosamine $(10 \%)$, muramic acid $(8 \%)$ and glucose $(4.5 \%)$.

The amino acids were estimated by the elution of ninhydrin-stained spots in a modification of the method of Kay, Harris \& Entenman (1956) and glucosamine and muramic acid by the method of 
J. T. Park (personal communication). Glucose was estimated as reducing sugar, after passing hydrolysates through columns of Dowex $50\left(\mathrm{H}^{+}\right)$to remove amino acids and amino-sugars. Liberation of the various components was followed during hydrolysis by $2 \mathrm{~N}-\mathrm{H}_{2} \mathrm{SO}_{4}$ at $100^{\circ}$. It was found that the amount of material measurable as $N$-acetylhexosamine reached a maximum value equivalent to $14 \%$ of the cell-wall after $20 \mathrm{~min}$. hydrolysis, and then declined with liberation of free hexosamine. Glucose was set free very rapidly, $90 \%$ within $20 \mathrm{~min}$. and $100 \%$ in $60 \mathrm{~min}$. Examination of cell-wall hydrolysed for $20 \mathrm{~min}$. showed that $98 \%$ of the material giving an $\mathrm{N}$-acetylhexosamine colour was dialysable. Most of this material could be eluted from cation exchange resins by water and was shown by paper chromatography to be $N$. acetylglucosamine and $N$-acetylmuramic acid. The remainder appeared in the first fractions eluted by $0.3 \mathrm{~N}-\mathrm{HCl}$ (i.e. before the amino-sugars). These fractions showed several slow-running spots on paper chromatography in butanol-acetic acid- water, which were visualized either with ninhydrin or with the Elson-Morgan reagents.

Each of the spots was eluted from the paper and examined by paper electrophoresis. Several fractions were obtained as follows: Fraction A, which gave a weak reaction for hexosamine before hydrolysis, contained principally glucosamine and muramic acid in equimolecular proportions. Fraction B, which also gave a weak hexosamine reaction before hydrolysis, contained glucosamine, muramic acid and glycine in the molecular proportions of $2: 1: 2$. Fraction $\mathrm{C}$, which gave a $N$ acetylhexosamine reaction before hydrolysis, contained alanine, glutamic acid, glycine, lysine and muramic acid in the proportions $4: 2: 3: 2: 2$.

\section{REFERENCES}

Cummins, C. S. \& Harris, H. (1956). J.gen. Microbiol. 14, 583.

Kay, R. E., Harris, D. C. \& Entenman, C. (1956). Arch. Biochem. Biophys. 63, 14.

Tracer Studies of the Metabolism of the Tumour Inhibitor Triethylenethiophosphoramide. By A. W. Craig, B. W. Fox and H. JACkson. (E.R.T. Department, Christie Hospital and Holt Radium Institute, Withington, Manchester 20)

In an earlier publication a study of the metabolism of triethylenephosphoramide labelled with radioactive phosphorus was reported (Craig \& Jackson, 1955). In the rat over $80 \%$ of the radioactivity is excreted in the urine in $24 \mathrm{hr}$., mainly as unchanged drug. This suggested that although triethylenephosphoramide is highly effective as an inhibitor of certain experimental tumours in the rat, it is not particularly reactive in vivo.

Tracer studies in mice with another ethyleneimino compound, triethylenemelamine, have been made by Nadkarni, Goldenthal \& Smith (1954). Only cyanuric acid was found in the urine, from which they concluded that compounds of this type have a marked chemical reactivity in the body. More recently Heidelberger and his associates examined the metabolism in tumour patients of labelled morpholinodiethylenethiophosphoramide. They identified substantial amounts of morpholinodiethylenephosphoramide in the urine, the sulphur in the drug having been replaced by oxygen; the major metabolite in the rat was the same (Maller \& Heidelberger, 1957).

In view of the above differences we have now examined the metabolism in three species-dog, rat and mouse - of triethylenethiophosphoramide labelled with radioactive phosphorus. Radioactive material was excreted very rapidly in all cases, but whereas the main urinary metabolite in the rat appears to be triethylenephosphoramide, i.e. the sulphur of the drug having been replaced by oxygen, in the mouse the drug is completely broken down to inorganic phosphate. Urine from the dog contained not only triethylenephosphoramide but also a considerable proportion of an unidentified metabolite. These differences in the metabolism of compounds containing ethyleneimino-groups may help to explain the observed variations in their effectiveness against tumours in different species. Conclusions as to the chemical reactivity of these compounds in vivo can be misleading if based on their metabolic fate in a single species.

\section{REFERENCES}

Craig, A. W. \& Jackson, H. (1955). Brit. J. Pharmacol. 10, 321.

Maller, R. K. \& Heidelberger, C. (1957). Cancer Res. 17, 296.

Nadkarni, M. V., Goldenthal, E. I. \& Smith. P. K. (1954). Cancer Res. 14, 559. 
Biochemical Differentiation between Radio-sensitive and Non-sensitive Tissues in the Rat. By W. A. Creasey and L. A. Stocken. (Department of Biochemistry, University of Oxford)

In order to obtain a clue to the fundamental lesion in radiation damage, a comparison has been made between the enzymic composition of nuclei prepared from radio-sensitive and non-sensitive tissues. About thirty nuclear enzymes are known, but up to the present we have only one test system which differentiates between the two kinds of tissue.

Osawa, Allfrey \& Mirsky (1957) have shown that calf-thymus nuclei, prepared in a sucrose medium, will phosphorylate the intranuclear adenine, guanine and uridine monophosphates to the corresponding triphosphates when shaken aerobically at $0^{\circ}$ in the medium. We have prepared nuclei from the radio-sensitive tissues thymus, spleen, lymph node, intestinal mucosa and bone marrow and from the non-sensitive liver, kidney, brain and pancreas. The nuclear suspensions were shaken for 30-40 min. at $0^{\circ}$ and samples obtained at the beginning and end of the experiment were freed from protein by means of perchloric acid. Labile phosphate was determined by heating the samples in $\mathrm{N}-\mathrm{HCl}$ at $100^{\circ}$ for $10 \mathrm{~min}$. The rate of generation of labile phosphate expressed in $\mu \mathrm{g}$. phosphorus/ mg. deoxyribonucleic acid phosphorus/min. is for thymus $0 \cdot 31$, spleen $0 \cdot 71$, lymph node $1 \cdot 83$, bone marrow 8.3 and intestinal mucosa $0 \cdot 31$. The nonsensitive tissues do not show any increase.

The effect of small doses of radiation on this nuclear phenomenon is quite marked. $100 \mathrm{r}$. total body radiation given to rats which are killed $1 \mathrm{hr}$. later, completely suppresses the high-energy phosphate generation, while even as low a dose as $25 \mathrm{r}$. leads to a $50-80 \%$ inhibition of the reaction.

As is to be expected, there is a recovery of the reaction in the tissues of rats exposed to sublethal doses but not in those given $1000 \mathrm{r}$. Such recovery has been followed in the spleen and thymus after $100 \mathrm{r}$. whole body irradiation. Recovery commences in the third day and is complete in about $100 \mathrm{hr}$. after the exposure to X-rays.

\section{REFERENCE}

Osawa, S., Allfrey, V. G. \& Mirsky, A. E. (1957). J. gen. Physiol. 40, 491.

The Purification of Pancreatic Lipase using Zone Electrophoresis on Plastic Sponge. By E. D. Wriss. (Department of Biochemistry, The Medical College of St Bartholomew's Hospital, London, E.C. 1)

Pancreatic lipase has been purified by means of a simple method based on one originally described by Glick \& King (1933).

A standard acetone powder of hog pancreas prepared as described by Wills (1954) was extracted 4 times with distilled water. The $\mathrm{pH}$ of the combined extracts was adjusted to $5 \cdot 0$ and $\mathrm{MgSO}_{4}, 7 \mathrm{H}_{2} \mathrm{O}$ (1 g./ml.) was added, causing the formation of a precipitate containing practically all the original lipase activity. This precipitate was filtered off, suspended in a small volume of water and dialysed against acetic acid-sodium acetate buffer $\left(10^{-3} \mathrm{M}, \mathrm{pH} \mathrm{5.5}\right)$ for 24-48 hr. The suspension clarified initially, but subsequently a precipitate formed which was centrifuged and dissolved in a small volume of $\mathrm{NaCl}(5 \%, \mathrm{w} / \mathrm{v})$. The resulting solution had a lipase activity/mg. protein ratio about 20 times that of the original extract.

Further purification of the enzyme was achieved by electrophoresis on plastic sponge using an apparatus similar to that outlined by Davidson (1957). This technique will be described.

At $\mathrm{pH} \mathrm{9.0} \mathrm{in} \mathrm{either} \mathrm{borate} \mathrm{or} \mathrm{tris-} \mathrm{HCl}$ buffer the purified preparation was separated into several components by this technique, but the major portion of the lipase activity was found to be associated with one component only, whose electrophoretic mobility suggests that its isoelectric $\mathrm{pH}$ is about $4 \cdot 5-5 \cdot 0$. The purified component was found to hydrolyse a variety of triglycerides and monoglycerides and to exhibit generally a low specificity similar to that of the crude extract.

\section{REFERENCES}

Davidson, H. M. (1957). Fed. Proc. 16, 169.

Glick, D. \& King, C. G. (1933). J. Amer. chem. Soc. 55, 2445.

Wills, E. D. (1954). Biochem. J. 57, 109. 
The Oxidation of Tricarboxylic Acid Cycle Intermediates by Pseudomonas aeruginosa. By Pauline Meadow* and Patricia Clarke. (Department of Biochemistry, University College London),

Pseudomonas aeruginosa was grown in the presence of various intermediates of the tricarboxylic acid cycle. Whole cells and extracts were then compared for their activity towards these substrates in the Warburg apparatus.

All the substrates tested (succinate, fumarate, malate, pyruvate, acetate, $\alpha$-oxoglutarate and citrate) were oxidized linearly from the time of adding the substrate to citrate-grown cells. Cells grown with succinate, pyruvate, fumarate, malate and $\alpha$-oxoglutarate oxidized citrate only after a lag period of about $3 \mathrm{hr}$. Addition of $1 \mu \mathrm{mol}$. of any readily oxidized substrate shortened the lag period to about $2 \mathrm{hr}$. Similar, though shorter (10 min.), lag periods preceded oxidation of acetate by fumarate-, pyruvate-, malate- and $\alpha$-oxoglutarategrown cells, and also the oxidation of succinate and fumarate by acetate-grown cells. Addition of chloramphenicol $(40 \mu \mathrm{g} . / \mathrm{ml}$.) or 8-azaguanine, (100 $\mu \mathrm{g} . / \mathrm{ml}$.) prevented these adaptations to the substrates. All other substrates were oxidized without a lag period.

Extracts of cells grown on the various substrates were prepared by disintegration in the bacterial press, the debris being removed by centrifugation. Cell-free extracts were thus obtained which oxidized citrate, fumarate, succinate, malate and

$$
\text { * Beit Memorial Fellow. }
$$

acetate linearly from the time of substrate addition, even from those bacteria which showed apparent adaptation in whole cells. All the extracts, including those from pyruvate-grown cells, were inactive towards pyruvate. Chloramphenicol and 8-azaguanine had no effect on any of the extracts.

Kogut \& Podoski (1953) and Barrett \& Kallio (1953) concluded from their experiments with whole cells and extracts of $P$. fluorescens that the lag observed in the oxidation of certain tricarboxylic acid cycle intermediates by whole cells involved making the substrates accessible to the enzyme, either across the cell membrane or to some special site within the cell. More recent work (Cohen \& Monod, 1957) has shown that in Escherichia coli there are proteins (permeases) which are concerned solely with the transport of stereospecific substrates across the cell-wall. The effects of 8 azaguanine and chloramphenicol in preventing the adaptation of $P$. aeruginosa to certain substrates support the hypothesis that during these lag periods the necessary permeases are being synthesised.

\section{REFERENCES}

Barrett, J. T. \& Kallio, R. E. (1953). J. Bact. 66, 517. Cohen, G. N. \& Monod, J. (1957). Bact. Rev. 21, 169.

Kogut, M. \& Podoski, E. P. (1953). Biochem. J. 55, 800 .

Determination of Liver Glycogen by the Sulphuric Acid Reaction. By C. E. SearLe and D. L. Woodhouse. (Cancer Research Laboratories, The Medical School, Birmingham, 15)

Kemp \& Kits van Heijningen (1954) described an attractive micro-method for determining liver glycogen in which a deproteinized homogenate is heated with 3 vol. of $96 \% \mathrm{H}_{2} \mathrm{SO}_{4}$ giving a bluish pink colour, the optical density of which is measured at $520 \mathrm{~m} \mu$. However, when using this method to investigate the distribution of glycogen in the livers of rats fed 4-dimethylaminoazobenzene, orange-pink solutions were obtained, although glucose gave the correct colour. In order to investigate whether this alteration might indicate qualitative changes in liver carbohydrates during carcinogenesis, experiments on the applicability of the method have been carried out.

Solutions obtained from tumorous liver samples showed high absorption over much of the 400$500 \mathrm{~m} \mu$ range, the $520 \mathrm{~m} \mu$ maximum being sometimes lower than a maximum at $480 \mathrm{~m} \mu$. Solutions from normal rat livers also had somewhat higher relative absorption between 400 and $500 \mathrm{~m} \mu$ than those from standard glucose solutions. The differences were more marked in the absorption spectra of solutions from muscle (Kemp \& Kits van Heijningen, 1954) or blood (Mendel, Kemp \& Myers, 1954), though visually the colours were normal.

The method is stated (Mendel et al. 1954) to be specific for certain hexoses and their derivatives, but since arabinose, xylose and rhamnose give pale yellow colours it seemed likely that ribose and deoxyribose would also react. Solutions of RNA and DNA gave pale yellow colours after treating by the deproteinization and colorimetric procedures, this being ascribed to the pentose units, since pure purines and pyrimidines gave no colour whatever. DNA gave a peak at $472 \mathrm{~m} \mu$, and RNA a number of smaller ill-defined maxima in the $400-600 \mathrm{~m} \mu$ range. Both showed appreciable absorption at 
$520 \mathrm{~m} \mu$, equivalent to about $20 \%$ of that given by an equal concentration of glucose.

While the method evidently yields satisfactory values in suitable tissues, errors due to the above and other factors can be great, particularly when the glycogen content is low.

\section{REFERENCES}

Kemp, A. \& Kits van Heijningen, A. J.M. (1954). Biochem. J. 56, 646 .

Mendel, B., Kemp, A. \& Myers, D. K. (1954). Biochem. J. 56, 639 .

The Determination of 11-Deoxy-17-oxosteroids in Urine from Adrenalectomized Women. By R. D. Bulbrook, F. C. Greenwood and B. S. Thomas. (Imperial Cancer Research Fund, Royal College of Surgeons, Lincoln's Inn Fields, London, W.C. 2)

The method of Kellie \& Wade (1957) was tested to determine whether it could be used for the accurate estimation of dehydroepiandrosterone, androsterone and aetiocholanolone in urine from adrenalectomized women. In our hands the method was found suitable only for qualitative detection of these compounds in this type of urine.

In most cases considerable amounts of pigment were present in the urinary extracts. Removal of the pigment by Girard separation occasionally led to acetate formation, even in the cold. The acetates of the 11-oxygenated 17-oxosteroids were eluted with the 11-deoxy steroids and the Girard separation was therefore abandoned. Since most of the interference was due to indigo red, this pigment was removed by reduction with alkaline sodium dithionite. A more serious source of interference was traced to unidentified Zimmerman chromogens, eluted from the column with the 11-deoxy-17oxosteroids. Ten such chromogens have been found, despite either Girard separation or dithionite reduction.

When eluates from the column were further resolved by paper chromatography it was found that most patients continued to excrete aetiocholanolone after adrenalectomy. Androsterone was rarely found. Dehydroepiandrosterone was found in one case where there was other evidence for incomplete adrenalectomy.

\section{REFERENCE}

Kellie, A. E. \& Wade, A. P. (1957). Biochem. J. 66, 196.

Oxygen Consumption and Loss of Activity of Heart-muscle Succinic Oxidase Preparations Deficient in Inorganic Phosphate. By M. B. THoRN. (Department of Biochemistry, St Thomas's Hospital Medical School, London, S.E. 1)

Heart-muscle preparations containing little inorganic phosphate readily lose succinic oxidase and succinate-methylene blue reductase activity on storage (Ball \& Cooper, 1949; Thorn, 1956). Succinic oxidase activity in low-phosphate media is activated by compounds (e.g. phosphate, histidine, ethylenediaminetetraacetate) which neither affect succinate-methylene blue reductase activity (Keilin \& Hartree, 1949; Slater, 1949 $a$; Bonner, 1954) nor restore activity to aged preparations. The problems of ageing and of activation, although perhaps related, are therefore different.

Ball \& Cooper (1949) found that phosphate and fluoride together were particularly effective in protecting their low-phosphate preparations from loss of activity. Slater \& Bonner (1952) showed that phosphate and fluoride together competitively in- hibited succinic dehydrogenase, and this observation, coupled with the fact that competitive inhibitors of succinic dehydrogenase protect it from sulphydryl reagents (Hopkins, Morgan \& LutwakMann, 1938; Potter \& DuBois, 1943), prompted the hypothesis, here advanced, that low-phosphate preparations might lose activity because of oxidation of sulphydryl groups. This hypothesis was strengthened by the following observations: (a) phosphate and fluoride together protected succinic dehydrogenase from inhibition by $p$ aminophenylarsenoxide (this is supported by the detailed work of Stoppani \& Brignone (1956)), (b) malonate was a highly effective protective agent, (c) the enzyme was well protected under anaerobic conditions. On the other hand, the conclusion of Ball \& Cooper (1949), that loss of activity was the result of breakdown of a 
phosphorylated compound, was weakened, in the present work, by the finding that competitive inhibitors and anaerobic conditions did not significantly affect the appearance of inorganic phosphate in the preparation. The 'oxidation hypothesis' is not in conflict with many studies (e.g. MacFarlane, 1950; Nygaard, 1953; Edwards \& Ball, 1954) which have shown, by the use of specific phospholipases, that phospholipids are important structural elements of these enzyme-bearing particles.

The oxygen consumption of heart-muscle preparations in the absence of added substrate $\left(Q_{0}\right.$ at $\left.37^{\circ}<1\right)$ has characteristics of a nonenzymic autoxidation, and is believed to be closely related to the loss of activity on ageing. The effects of this oxygen consumption will be compared with the effects (Slater, 1949 $b$ ) of oxidizing agents ( $o$ iodosobenzoate and oxidized glutathione), and of low concentrations of BAL in air (Slater, 1949c).

\section{REFERENCES}

Ball, E. G. \& Cooper, O. (1949). J. biol. Chem. 180, 113. Bonner, W. D. jun. (1954). Biochem. J. 56, 274.

Edwards, S. W. \& Ball, E. G. (1954). J. biol. Chem. 209, 619.

Hopkins, F. G., Morgan, E. J. \& Lutwak-Mann, C. (1938). Biochem. J. 32, 1829.

Keilin, D. \& Hartree, E. F. (1949). Biochem. J. 44, 205.

MacFarlane, M. G. (1950). Biochem. J. 47, xxix.

Nygaard, A. P. (1953). J. biol. Chem. 204, 655.

Potter, V. R..\& DuBois, K. P. (1943). J.gen. Physiol. 26, 391.

Slater, E. C. $(1949 a)$. Biochem. J. 45, 8.

Slater, E. C. (1949b). Biochem. J. 45, 130.

Slater, E. C. $(1949 c)$. Biochem. J. 45, 14.

Slater, E. C. \& Bonner, W. D. jun. (1952). Biochem. J. 52 , 185.

Stoppani, A. O. M. \& Brignone, J. A. (1956). Biochem. J. 64, 196.

Thorn, M. B. (1956). Biochem. J. 63, 420.

\section{Ascorbic Oxidase Activity in Extracts from Higher Plants. By V. S. ButT and Mary Hatraway. (Department of Botany, University of Oxford)}

Ascorbate is readily oxidized in tissue extracts from higher plants. Agents which may catalyse the reaction include not only ascorbic oxidase, but also cytochrome oxidase, peroxidase, polyphenolase, unbound copper ions and copper-protein complexes. As the first step in an investigation of the function of ascorbic oxidase in plants, methods have been developed to distinguish the activity of this enzyme from that of the other catalysts.

From a comparative study of the kinetics of copper-ion catalysis and of that by an enzyme extracted and purified from vegetable marrow, it is proposed that ascorbic oxidase activity can be recognized in homogenates buffered at $\mathrm{pH} 6.0$ by (i) a rapid copper turnover, (ii) identical rates of oxidation of $4 \mathrm{~mm}$ - and $40 \mathrm{~mm}$-ascorbate, (iii) its insensitivity to 2 mM-EDTA, (iv) its complete inhibition by $0.1 \mathrm{~mm}$-sodium diethyldithiocarbamate and by $1 \mathrm{mm-8-hydroxyquinoline,} \mathrm{(v)} \mathrm{its}$ inability to catalyse the oxidation of $4 \mathrm{~mm}$ catechol or 4 mM-quinol.

These tests have been applied to a selection of plant extracts, in most of which the enzyme was found to be active. Deviations from these characteristics have been observed in preparations from potato, cabbage leaf and barley seedlings. In squash juice, the reaction inactivation reported for the purified enzyme (Powers \& Dawson, 1943) does not take place; in all crude extracts examined, the oxidation proceeds to completion.

\section{REFERENCE}

Powers, W. H. \& Dawson, C. R. (1943). J. gen. Physiol. 27, 181.

The Absorption of Vitamin $\mathbf{B}_{12}$ in the Rat. By M. E. CoAtes and E. S. Holdsworth. (National Institute for Research in Dairying, Shinfield, $n r$ Reading, Berkshire)

Adult rats and ${ }^{60} \mathrm{Co}$-labelled vitamin $\mathrm{B}_{12}$ were used in these experiments and all ${ }^{60} \mathrm{Co}$ determinations were made by scintillation counting. The radioactivity found in the gut wall after oral dosing with $25 \mu \mathrm{mg}$. vitamin $\mathrm{B}_{12}$ confirmed the finding of Booth, Chanarin, Anderson \& Mollin (1957) among others that the ileum is the most active site of absorption of the vitamin in the rat. The total counts in lymph obtained by cannulation of the main mesenteric lymphatic duct showed that lymph is much less important than the blood stream as a route of absorption.

In an extension of our previous work (Holdsworth \& Coates, 1956), three intestinal loops of equal length, each containing $10 \mu \mathrm{mg}$. vitamin $B_{12}$, were established in rats. The animals were killed after $18 \mathrm{hr}$. and the loops and various organs examined. The greatest absorption took place in 
the middle and lower loops. Rats which received vitamin $B_{12}$ alone absorbed about $13 \%$ of the dose during the experiment. Addition of rat-stomach extract increased absorption to $40 \%$, but clinically active preparations of pig intrinsic factor reduced absorption to $9 \%$. With a sample of human gastric juice known to be active in pernicious anaemia the absorption in the two upper loops was not greatly different whether the vitamin $B_{12}$ was given alone or with human gastric juice. In the lowest loop, however, human gastric juice increased absorption from 10 to $24 \%$. This observation might provide the basis for any assay of intrinsic factor activity of human gastric juice.

The maximal absorption of vitamin $B_{12}$ within a defined area suggested the existence of special receptor cells in that region. Preparations of washed surviving mucosal cells from the three portions of the small intestine were incubated for $1 \mathrm{hr}$. with vitamin $B_{12}$ at $37^{\circ}$ in Krebs-Ringer bicarbonate glucose. The cells were separated and washed. Results followed closely those with live animals, in that the greatest uptake of vitamin $B_{12}$ occurred in cells from the middle portion of the intestine; uptake was nearly doubled by rat-stomach extract and partially inhibited by pig intrinsic factor. Contrary to the in vivo findings, human gastric juice inhibited uptake of vitamin $B_{12}$ by the mucosal cells, particularly in the lowest portion of the gut where it had been most active in the live animal.

\section{REFERENCES}

Booth, C. C., Chanarin, L., Anderson, B. B. \& Mollin, D. L. (1957). Brit. J. Haemat. 3, 253.

Holdsworth, E. S. \& Coates, M. E. (1956). Nature, Lond., 177, 701.

Metabolism of further 11-Oxygenated Steroids. By I. E. BuSH and V. B. MaHESH. (Radcliffe Infirmary, Oxford)

Reduction of the steroid 11-ketone group in vivo is of interest because it seems likely that 11-oxo adrenal steroids must be reduced to the $11 \beta$-ols before biological activity appears (Bush, 1956; Bush \& Mahesh, 1957; Glenn, Stafford, Lyster \& Bowman, 1957). It has been suggested that this reaction in vivo occurs only with steroids having a relatively flat $\alpha$-surface over rings $A$ and $B$ (Bush, 1956; Bush \& Mahesh, 1957). Pursuing this topic we have now examined the urinary metabolites of $2 \alpha$-methyladrenosterone (I), allotetrahydrocortisone (II), tetrahydrocortisone (III), and prednisone (IV) after oral administration to young men.

$40 \mathrm{mg}$. I gave rise to $2 \alpha$-methyl-11 $\beta$-hydroxyandrostenedione, I, $2 \alpha$-methyl-17 ?-hydroxyandrost4-ene-3:11-dione, 2 $\alpha$-methyl-11 $\beta$ :17 ?-dihydroxyandrost-4-en-3-one, $2 \alpha$-methyl-3 $\alpha$-hydroxy-5 $\alpha$-androstane-11:17-dione, and an unidentified diol (total $12 \mathrm{mg}$.). The ratio I: $2 \alpha$-methyl-11 $\beta$-hydroxyandrostenedione was $\mathbf{1 . 4 5}$. Reduction of the IIketone was thus more complete than in the case of 2 $\alpha$-methylcortisone (Bush \& Mahesh, 1957).

$50 \mathrm{mg}$. II gave $1 \cdot 1 \mathrm{mg}$. II, $9 \cdot 2 \mathrm{mg}$. allotetrahydrocortisol, and $0.97 \mathrm{mg}$. $11 \beta$-hydroxyandrosterone. $60 \mathrm{mg}$. III gave $10.7 \mathrm{mg}$. III, $0.6 \mathrm{mg}$. tetrahydrocortisol, and $0.87 \mathrm{mg}$. 11-oxoaetiocholanolone. $50 \mathrm{mg}$. IV gave, among others, $1.0 \mathrm{mg}$. IV and $1.2 \mathrm{mg}$. prednisolone.

In these experiments the 11-ketone: $11 \beta$-ol ratio was found in each case to be the same in plasma as in the urine.
These results confirm the hypothesis that the main factor determining the possibility of reduction of steroid 11-ketone groups in man is the stereochemistry of the AB ring system (Bush, 1956) rather than the presence or absence of a $\Delta^{4}$-3-ketone group (Fukushima, Hubener \& Gallagher, 1956). Prednisone is particularly interesting in that the angulation of the $A / B$ ring junction is intermediate between the flat trans and the fully bent cis forms of the saturated 3-hydroxy steroids.

The relative incompleteness of reduction of prednisone (50\%, against $90 \%$ of cortisone) was correlated with a significant reduction in the biological activity of prednisone (11-oxo) (judged by adrenal suppression) compared with prednisolone (11 $\beta$-ol). This is similar to, but less striking than, the same associated findings with $2 \alpha$-methylcortisone (Bush \& Mahesh, 1957, 1958).

These results also confirm the supposition (Dorfman, 1954) that 17-oxosteroids can arise from saturated 3-hydroxy-steroids like II and III.

With the doses employed it is reasonable to assume that the observed 11-oxo:11 $\beta$-hydroxyl ratios are determined, with these steroids, by the rate of 11-oxo reduction and not to any significant extent by differences in redox potential of the 11 . oxygen functions of the steroids concerned.

We are grateful in this and earlier studies for gifts of steroids from the Upjohn Company, U.S.A., Dr B. Hems (Glaxo Laboratories), Dr R. K. Callow (M.R.C.), Dr C. Hewett (Organon) and Dr M. Elyan (Roussel Laboratories). 


\section{REFERENCES}

Bush, I. E. (1956). Experientia, 12, 325.

Bush, I. E. \& Mahesh, V. B. (1957). Biochem. J. 66, 56 P.

Bush, I. E. \& Mahesh, V. B. (1958). Biochem. J. (in the Press).
Dorfman, R. I. (1954). Recent Progress Hormone Research, $9,5$.

Fukushima, D. K., Hubener, H. J. \& Gallagher, T. F. (1956). J. biol. Chem. 220, 499.

Glenn, E. M., Stafford, R. O., Lyster, S. C. \& Bowman, B. J. (1957). Endocrinology, 61, 128.

\section{Indolylacetamide - a Chromatographic Artifact from the Natural Indoles, Indolylacetylgluco- siduronic Acid and Indolylpyruvic acid. By J. B. Jepson. (Courtauld Institute, Middlesex Hospital Medical School, London, W. 1)}

During investigations into the biochemical lesion of Hartnup disease (Baron, Dent, Harris, Hart \& Jepson, 1956; Jepson, 1956), normal subjects have been given single doses of indolylacetic acid (IAA) and the subsequent changes in urinary excretion patterns examined.

When such urines were subjected to two-way paper chromatography in isopropanol-ammonia/ butanol-acetic acid, a solvent pair recommended for the separation of indoles (Jepson, 1958), 3indolylacetamide was found on the chromatogram. This seemed an unlikely metabolite and could not be isolated from the urine itself. Further experiments showed that it only appeared when ammoniacal solvents were used for the chromatography. If these were avoided, a new indolic component was revealed, subsequently isolated from the urine by solvent partition and shown to be indolylacetyl glucosiduronic acid, a new human conjugate of IAA.

This acyl-glucuronide is extremely rapidly converted to glucuronic acid and IAA by alkali, to indolylacetamide by ammonia, and to indolylacethydroxamic acid by neutral hydroxylamine-a reaction used for its determination in urine (cf. Schachter, 1957). It is hydrolysed by $\beta$-glucuronidase preparations. A $500 \mathrm{mg}$. oral dose of IAA is largely accounted for in the urine of the subsequent $24 \mathrm{hr} .-200 \mathrm{mg}$. as the glucuronide and the rest as free IAA and indolylacetylglutamine (Jepson, 1956). Many normal urines contain traces of the glucuronide, which changes to IAA and indolylacetamide if the urine becomes ammoniacal or on chromatography in ammonia. Urines from cases of Hartnup disease have only moderate amounts.

In a search for other natural indoles which would yield IAA or indolylacetamide on chromatography in ammoniacal solvents, the alkaline degradation of indolylpyruvic acid (IPyA) was reinvestigated [in collaboration with Dr Joyce Bentley, Marine Laboratory, Aberdeen]. Chromatography in isopropanol-ammonia of fresh IPyA gave indolylacetamide in 5-10\% yield. As well as IAA and indolylglycollic acid (already reported by Bentley, Farrar, Housley, Smith \& Taylor, 1956), another surprising product was indole-3-carboxylic acid. It seems unlikely that any IPyA was left (contrast the conclusions of Stowe \& Thimann, 1954; Schwarz \& Bitancourt, 1957) since no area of a one-way chromatogram gave indolyl-lactic acid after reduction with sodium borohydride-a device which succeeded with chromatograms from acid solvents.

Thanks are due to C. P. Berg, K. R. Farrar, G. B. Leyton, and B. B. Stowe for samples of indolylpyruvic acid.

\section{REFERENCES}

Baron, D. N., Dent, C. E., Harris, H., Hart, E. W. \& Jepson, J. B. (1956). Lancet, 2, 421.

Bentley, J. A., Farrar, K. R., Housley, S., Smith, G. F. \& Taylor, W. C. (1956). Biochem. J. 64, 44.

Jepson, J. B. (1956). Biochem. J. 64, 14 P.

Jepson, J. B. (1958). In Chromatographic Techniques, chap. 5. Ed. Smith, I. London: Heinemann.

Schachter, D. (1957). J. clin. Invest. 36, 297.

Schwarz, K. \& Bitancourt, A. A. (1957). Science, 126, 607. Stowe, B. B. \& Thimann, K. V. (1954). Arch. Biochem. Biophys. 51, 499.

The Free Glycine Metabolic Pool in Man. By J. C. Crawhall and R. W. E. Watts. (The Medical Unit, St Bartholomew's Hospital, London, E.C. 1)

Study of the free glycine metabolic pool in man has been handicapped by the lack of a satisfactory method of sampling the pool after the administration of the isotopically labelled amino acid. The hippuric acid excreted after a loading dose of sodium benzoate has been used for this purpose
(Gray \& Neuberger, 1950; Berlin, Hewitt \& Lotz, 1954). The validity of this can be questioned (see, for example, Gray \& Neuberger, 1950), and we suggest that the uncombined urinary glycine may be regarded as a representative sample of the free glycine metabolic pool. In the present work, the 
isotope content of the urinary hippuric acid after the oral administration of ${ }^{15} \mathrm{~N}$-labelled glycine has been compared with that of the uncombined glycine in the same urine specimen; loading doses of benzoate were not given. After extraction of the hippuric acid, the uncombined urinary aminoacids were benzoylated, and the mixed benzoyl derivatives extracted and hydrolysed. The mixed amino acids obtained were coupled with 1-fluoro2:4-dinitrobenzene and the glycine derivative separated chromatographically essentially as described by Krol (1952). The ${ }^{15} \mathrm{~N}$-content of the hippuric acid was consistently between two and three times greater than the ${ }^{15} \mathrm{~N}$-content of the corresponding uncombined urinary glycine. This result could arise if the glycine moeity of hippuric acid were derived, in part at least, preferentially from dietary glycine before the latter had become uniformly distributed in the free-glycine metabolic pool.

We are using the uncombined urinary glycine as a means of investigating the free glycine metabolic pool size and turnover rate and suggest preliminary figures of $6.3 \mathrm{~g}$. $(\equiv 0.12 \mathrm{mmol} . / 100 \mathrm{~g}$. body weight) and $1.5 \mathrm{~g} . / \mathrm{hr}$. ( $\equiv 0.68 \mathrm{mmol} . / \mathrm{day} / 100 \mathrm{~g}$. body weight) for the pool size and turnover rate in a $70 \mathrm{~kg}$. adult respectively. The former result, related to $100 \mathrm{~g}$. body weight is similar to the value (about $0.13 \mathrm{mmol} . / 100 \mathrm{~g}$.) obtained by Arnstein \& Neuberger (1951) in a different type of experiment for what they termed 'the first glycine metabolic pool' in the rat.

We are pleased to acknowledge our indebtedness to Professor A. Wormall, F.R.S., for the provision of facilities for the mass spectrometric analyses.

\section{REFERENCES}

Arnstein, H. R. V. \& Neuberger, A. (1951). Biochem. J. $50,154$.

Berlin, N. I., Hewitt, C. \& Lotz, C. (1954). Biochem. J. 58, 498.

Gray, C. \& Neuberger, A. (1950). Biochem. J. 47, 81.

Krol, S. (1952). Biochem. J. 52, 227.

Ethylmercapturic Acid and its Formation in vivo. By A. E. R. Thomson, G. A. MAw and L. Young. (Department of Biochemistry, St Thomas's Hospital Medical School, London, S.E. 1)

It has been reported by Roberts \& Warwick (1957) that the administration of ethyl methanesulphonate, $\mathrm{CH}_{3} \cdot \mathrm{SO}_{2} \cdot \mathrm{O} \cdot \mathrm{C}_{2} \mathrm{H}_{5}$, to rats is followed by the excretion of two sulphur-containing acids, one of which is ethylmercapturic acid ( $N$-acetyl-S ethyl-L-cysteine) and the other possibly the corresponding $\alpha$-keto acid. In the present work we have obtained evidence that the administration of bromoethane to rats leads to the excretion of ethylmercapturic acid in the urine:

$$
\mathrm{C}_{2} \mathrm{H}_{5} \mathrm{Br} \rightarrow \mathrm{C}_{2} \mathrm{H}_{5} \cdot \mathrm{S} \cdot \mathrm{CH}_{2} \cdot \mathrm{CH}\left(\mathrm{NH} \cdot \mathrm{CO} \cdot \mathrm{CH}_{3}\right) \cdot \mathrm{CO}_{2} \mathrm{H}
$$

Our observations, together with those described in the following paper by Bray \& James (1958), suggest that mercapturic acid formation may be a general metabolic reaction for alkyl halides.

$S$-Ethyl-L-cysteine was prepared by the ethylation of L-cysteine in anhydrous ammonia with iodoethane and was converted to ethylmercapturic acid by the action of ketene. The mercapturic acid was also prepared by the ethylation of $N$-acetyl-Lcysteine in anhydrous ammonia. The synthetic products were used as reference compounds in studies of the urine of rats dosed with bromoethane by subcutaneous injection (1.25 g. $\mathrm{C}_{2} \mathrm{H}_{5} \mathrm{Br} /$ kg. body wt. as a $40 \%(w / v)$ solution in arachis oil). Examination of the urine by paper chromatography using three different solvent systems indicated the presence of ethylmercapturic acid, and chloroform extracts of the acidified urine were also found to contain the compound. Ethylmercapturic acid was detected by spraying the chromatograms with $0 \cdot 1 \mathrm{M}-\mathrm{K}_{2} \mathrm{Cr}_{2} \mathrm{O}_{7}$-acetic acid $(1: 1)$ and then with 0.1 M- $\mathrm{AgNO}_{3}$, as was used by Knight \& Young (1957) for the detection of premercapturic acids and mercapturic acids. Paper chromatography also showed that ethylmercapturic acid disappeared from the urine when it was hydrolysed with hot $\mathrm{HCl}$, and that this was accompanied by the appearance of $S$-ethyl-L-cysteine.

Radiochromatographic studies were made on the urine of rats which had been maintained on a diet containing yeast proteins in which the sulphurcontaining amino acids were labelled with ${ }^{35} \mathrm{~S}$. The administration of bromoethane to these animals was followed by the appearance on the chromatograms of two radioactive spots. One of these has not been identified and the other corresponded to ethylmercapturic acid. The mercapturic acid spot was absent from chromatograms of the acid-hydrolysed urine, which did, however, show a radioactive spot corresponding to $S$-ethyl-Lcysteine.

\section{REFERENCES}

Bray, H. G. \& James, S. P. (1958). Following abstract. Knight, R. H. \& Young, L. (1957). Biochem. J. 66, $55 \mathrm{P}$.

Roberts, J. J. \& Warwick, G. P. (1957). Nature, Lond., 179, 1181. 
The Formation of Mercapturic Acids from Aliphatic Compounds in vivo. By $H$. G. BraY and SyBIL P. JAmes. (Physiology Department, Medical School, University of Birmingham)

Until recently all the mercapturic acids reported in the literature had their acetylcysteyl radical attached either directly to an aromatic nucleus (e.g. $\quad N$-acetyl-S-(4-chlorophenyl)-L-cysteine, $N$ acetyl-S-(1-naphthyl)-L-cysteine, $\quad N$-acetyl-S-(2chloro-4-nitrophenyl)-L-cysteine) or at the end of a side chain attached to an aromatic nucleus (e.g. $N$-acetyl-S-benzyl-L-cysteine). Roberts \& Warwick (1957) reported the excretion by rats of $N$-acetyl-S-ethyl-L-cysteine after administration of ethyl methanesulphonate and Thomson, Maw \& Young (1958) now report that this mercapturic acid can be formed by rats from bromoethane. We have obtained evidence that the rabbit excretes mercapturic acids after the administration of 1-bromobutane, -pentane, -hexane, -heptane and octane. These are believed to be formed, in effect, by acetylcysteyl debromination, e.g. the product from 1-bromobutane is $N$-acetyl-S-butyl-L-cysteine. The percentage of the dose excreted as mercapturic acid decreases as the chain length increases. Evidence has also been obtained that mercapturic acids are formed from 2-bromobutane and bromocyclohexane and that small amounts of mercapturic acid may be formed, presumably by acetylcysteyl denitration, from 1-nitroethane and 1-nitropropane. The formation of mercapturic acid thus appears to be a general metabolic reaction of certain types of purely aliphatic compounds as well as of aromatic compounds.

\section{REFERENCES}

Thomson, A. E. R., Maw, G. A. \& Young, L. (1958). Preceding abstract.

Roberts, J. J. \& Warwick, G. P. (1957). Nature, Lond., 179, 1181.

Influence of Insulin and Adrenaline on the Incorporation of $\left.{ }^{14} \mathrm{G}\right] \mathrm{Glucose}$ into Free and Fixed Glycogen Fractions in the Isolated Diaphragm. By AdrIEnNe J. M. Kits van HeiJnINGEN and W. A. Bosch. (Pharmaco-therapeutic Laboratory, University of Amsterdam, Holland)

In the isolated diaphragm, incubated with glucose, insulin produces an increase in total glycogen (Gemmill, 1940), which is entirely accounted for by an increase in the free fraction (Kits van Heijningen, 1957). To elucidate whether the extra glucose is incorporated into the free fraction directly or via the fixed glycogen, diaphragms were incubated in media containing [U-14 C]glucose with and without insulin. Without insulin specific activities (s.A.) after $45 \mathrm{~min}$. were $2 \cdot 20 \pm 0 \cdot 56 \mathrm{c} / \mu \mathrm{g}$. $/ \mathrm{min}$. for free and $2.55 \pm 0.66$ for fixed glycogen, their rates of increase between 45 and $75 \mathrm{~min}$. running parallel to give final values of $3.74 \pm 0.67$ and $4.02 \pm 0.45$ respectively. Addition of insulin increases the S.A. of free glycogen to $6 \cdot 23 \pm 1.07$ after $45 \mathrm{~min}$., while no further increase in S.A. occurs between 45 and $75 \mathrm{~min}$. After $35 \mathrm{~min}$., when the increase in free glycogen content has not yet reached its maximum, the S.A. is already $6 \cdot 24$. In the fixed glycogen insulin increases the S.A. only to 3.75 after $45 \mathrm{~min}$., and neither the amount present nor the increase in s.A. between 45 and $75 \mathrm{~min}$. deviate from the control values. Although no figures for the period between 0 and $35 \mathrm{~min}$. could be obtained, the results are not suggestive of an indirect transfer of the extra glucose incorporated, not even if one takes into account that the outer branches of the tree-like glycogen molecule (Cori \& Larner, 1951) are metabolically more active than the inner stem (Stetten, Katzen \& Stetten, 1956).

If the free fraction serves to replete the fixed when glycogen stores are being drawn upon, the transfer of free to fixed glycogen should, after incubation with insulin, result in an increase in s.A. of the fixed fraction. Therefore, to induce glycogen breakdown, diaphragms preincubated in media containing $\left[{ }^{14} \mathrm{C}\right]$ glucose and insulin, were transferred to media containing adrenaline and inactive glucose or no glucose at all. Unexpectedly, however, it appeared that adrenaline will no longer cause a decrease in fixed glycogen when the diaphragm was pretreated with insulin. Yet the s.A. of this fraction decreases even if there is no glucose in the medium containing adrenaline. The possible significance of these findings will be discussed.

\section{REFERENCES}

Cori, G. T. \& Larner, J. (1951). J. biol. Chem. 188, 17.

Gemmill, Ch. L. (1940). Bull. Johns Hopk. Hosp. 66, 232.

Kits van Heijningen, A. J. M. (1957). Biochem. J. 65, 111.

Stetten, M. R., Katzen, H. M. \& Stetten, D. (1956). J. biol. Chem. 222, 587. 


\section{Identification of Amino Sugars. By M. J. CRUMPTon. (Microbiological Research Establishment, Porton, Wiltshire)}

The behaviour of amino sugars has been examined by chromatography on columns of Zeo-Karb 225 resin eluted with $0.33 \mathrm{~N}-\mathrm{HCl}$ by a modification (Rondle \& Morgan, 1955a) of the method of Gardell (1953). Samples (200 $\mu$ g.) of each sugar were examined alone and with added glucosamine; the glucosamine emerged in a peak position $(\mathrm{ml}$. effluent) which was reproducible for a particular column provided that $\mathrm{HCl}$ of the same normality was used.

Amounts of eluted sugar were estimated by the procedure of Rondle \& Morgan (1955b). Sugars producing chromophores whose absorption maxima were identical with that of glucosamine $(530 \mathrm{~m} \mu)$ were estimated using glucosamine standards. 'Muramic acid' (Strange, 1956; Kent, 1957) and D-fructosamine (Maurer \& Schiedt, 1935) however, gave absorption spectra with maxima at 505 and $550 \mathrm{~m} \mu$ respectively; these sugars were therefore estimated using standards of the same sugar, colour intensities being measured at the wavelength of maximum absorption. The absorption spectrum produced by the sugar eluted from the column in its peak position was measured, since in this way muramic acid and fructosamine could be differentiated from other amino sugars. The peak volume (ml. effluent) in which the sugar emerged was determined and has been expressed relative to that of glucosamine. The resultant ratio (' $R_{\text {glucosamine }}$ value') is independent of column length, amount of resin and the normality of the acid used for elution, at least within the range $0.25-0.50 \mathrm{~N}$. This property together with the absorption maximum of the chromophore are of use for the identification of amino sugars.

Equal weights of amino sugars ( $\mu$ g. as base) produced in the Rondle \& Morgan (1955b) test different colour intensities at $530 \mathrm{~m} \mu$. The amount of colour formed has been determined relative to that produced by an equal weight of glucosamine; these figures $(\% \pm 3 \%)$ are given in parenthesis following the $R_{\text {glucosamine }}$ values $( \pm 0.01)$ estimated from the column data: D-glucosamine uronic acid (Heyns \& Paulsen, 1955), 0.71 (100); a synthetic stereoisomer of muramic acid (Kent \& Strange, 1958), 0.87 ; D-mannosamine (Kuhn \& Bister, 1957), 1.07 (69) (cf. Comb \& Roseman, 1958); muramic acid, $1.10(27)$; D-galactosamine, 1.20; D-gulosamine (Tamelen, Dyer, Carter, Pierce \& Daniels, 1956), 1.21 (80); D-allosamine (from $N$-acetyl-Dallosamine; Jeanloz, 1957), 1-24 (83); D-xylosamine (from $N$-acetyl-D-xylosamine; Wolfrom \& Anno, 1953), 1.41; D-fructosamine, 1.52 (131); D-talosamine, 1.60 (112); D-fucosamine (Crumpton \& Davies, 1956), 1.94 (94).

I am greatly indebted to Professor K. Heyns, Dr R. W. Jeanloz, Major L. H. Kent, Professor R. Kuhn, Professor W. T. J. Morgan, F.R.S., Mr R. E. Strange, Dr E. E. van Tamelen and Professor M. L. Wolfrom for their generous gifts of amino sugars.

\section{REFERENCES}

Comb, D. G. \& Roseman, S. (1958). J. Amer. chem. Soc. 80, 497.

Crumpton, M. J. \& Davies, D. A. L. (1956). Biochem. J. 64, $22 \mathrm{P}$.

Gardell, S. (1953). Acta chem. scand. 7, 207.

Heyns, K. \& Paulsen, H. (1955). Chem. Ber. 88, 188.

Jeanloz, R. W. (1957). J. Amer. chem. Soc. 79, 2591.

Kent, L. H. (1957). Biochem. J. 67, 5 P.

Kent, L. H. \& Strange, R. E. (1958). Biochem. J. (in the Press).

Kuhn, R. \& Bister, W. (1957). Liebigs Ann. 602, 217.

Maurer, K. \& Schiedt, B. (1935). Ber. dtsch chem. Ges. 68, 2187.

Rondle, C. J. M. \& Morgan, W. T. J. (1955a). Biochem. J. 59, xiii.

Rondle, C. J. M. \& Morgan, W. T. J. (1955b). Biochem. J. 61, 586.

Strange, R. E. (1956). Biochem. J. 64, 23 P.

Tamelen, E. E., van Dyer, J. R., Carter, H. E., Pierce, J. V. \& Daniels, E. E. (1956). J. Amer. chem. Soc. 78, 4817.

Wolfrom, M. L. \& Anno, K. (1953). J. Amer. chem. Soc. 75, 1038.

The Effect of Haemorrhage on the Incorporation of $\left[\alpha-{ }^{14} \mathrm{C}\right] \mathrm{Glycine}$ into Stercobilin. By C. H. Gray and J. J. ScotT. (Departments of Chemical Pathology, King's College Hospital and St Mary's Hospital Medical Schools, London)

When $\left[\alpha^{-14} \mathrm{C}\right]$ glycine is fed to a healthy man, the resulting radioactivity of the faecal stercobilin shows two peaks, one at 115 days corresponding to the maximum rate of breakdown of the labelled red cells and one during the first 7 days. That fraction responsible for the first peak is here termed 'early' stercobilin. It has been suggested that it may arise in the bone marrow by premature breakdown of haemoglobin from intact red cells (London, Shemin, West \& Rittenberg, 1949; Gray, Neuberger \& Sneath, 1950) or from haem in excess of globin (Neuberger, Muir \& Gray, 1950). 
Formation other than from haemoglobin has been considered (London, West, Shemin \& Rittenberg, 1950); evidence was obtained (Berlin, Neuberger \& Scott, 1956) that some $\delta$-aminolaevulic acid is converted rapidly to stercobilin in man, haemoglobin not being an intermediate.

If formation of 'early' stercobilin is related to haemopoiesis there should be proportionality between haemopoietic activity of the marrow and the amount of radioactivity in 'early' stercobilin. The incorporation of $\left[\alpha-{ }^{14} \mathrm{C}\right]$ glycine into this fraction has therefore been studied before and after haemopoiesis had been stimulated by bleeding.

$\left[\alpha^{14} \mathrm{C}\right]$ Glycine was given orally on two occasions to a man of 53 years having very mild photosensitivity and slightly raised excretion of coproporphyrin; after each occasion faecal stercobilin was isolated at convenient intervals over 17 days. Four days before the second dose of $\left[\alpha-{ }^{14} \mathrm{C}\right]$ glycine, blood (1 1.) was removed, so that the isotope was administered when the response to haemorrhage was near its height, as judged by the reticulocyte count of the circulating blood. The findings to be presented show that the 'early' stercobilin was related to the rate of red cell production since the activity of stercobilin formed after haemorrhage was in- variably greater than that formed in the corresponding period before haemorrhage. Between the 5th and 8th days, when the difference was greatest, the specific activities differed by a factor of 3.4 . Throughout the 5 weeks of investigations the faecal excretion of coproporphyrin and protoporphyrin remained unchanged, averaging 1.8 and $0.5 \mathrm{mg} .1$ day respectively.

In addition to the findings obtained as a result of the removal of blood it is also clear, from comparison of the activities during the early maximum between days 2 and 5 and the later maximum at 115 days, that there was no significant increase in the amount of 'early' stercobilin relative to latelabelled stercobilin such as occurs in congenital porphyria.

\section{REFERENCES}

Berlin, N. I., Neuberger, A. \& Scott, J.J.(1956). Biochem. J. $64,80$.

Gray, C. H., Neuberger, A. \& Sneath, P. H. A. (1950). Biochem. J. 47, 87.

London, I. M., Shemin, D., West, R. \& Rittenberg. D. (1949). J. biol. Chem. 179, 463.

London, I. M., West, R., Shemin, D. \& Rittenberg, D. (1950). J. biol. Chem. 184, 365.

Neuberger, A., Muir, H. M. \& Gray, C. H. (1950). Nature, Lond., 165, 948.

The Separation of Monosaccharides on Charcoal-Gelite Columns. By J. S. D. BAcon. (Department of Biochemistry, Macaulay Institute, Aberdeen)

Chromatography on activated charcoal-Celite columns (Whistler \& Durso, 1950) has been applied very widely to the separation of oligosaccharides, particularly di- and trisaccharides, but monosaccharides are retained only slightly by the charcoals commonly used, and have usually been separated by partition chromatography on cellulose powder (Hough, Jones \& Wadman, 1949) or Celite (Lemieux, Bishop \& Pelletier, 1956).

Following an observation by Dr R. Côté, Dr W. J. Whelan has found an activated charcoal (Ultrasorb S.C. 120/40) which retains monosaccharides to a useful extent, and can thus be used to separate them from inorganic salts (Hughes \& Whelan, 1958). Dr M. J. Clancy in the same laboratory has developed the use of columns of this charcoal in a new preparative method for the isolation of pure L-fucose from its mixture with other monosaccharides in acid hydrolysates of Ascophyllum nodosum.

We also have examined the possibility of using columns of Ultrasorb-Celite to separate mixtures of monosaccharides. Of xylose, ribose, glucose, fructose, fucose and rhamnose the pentoses are least, and the 6-deoxyhexoses most, strongly adsorbed. 'Tailing' is noticeable even when gradient elution is employed. The useful capacity of the columns is low and the concentration of sugar in the effluent is barely sufficient for direct examination by paper chromatography. Examination of several batches of Ultrasorb (kindly supplied by British Carbo Norit Union Ltd., London Road, West Thurrock, Grays, Essex) showed no marked variation in its capacity to retain monosaccharides.

When $25 \mathrm{mg}$. quantities of xylose, glucose and rhamnose were applied to a column of $20 \mathrm{~g}$. Ultrasorb: $20 \mathrm{~g}$. Celite No. 535 and eluted by a gradient produced by dropping $4 \%(\mathrm{v} / \mathrm{v})$ ethanol into $500 \mathrm{ml}$. water (cf. Bacon \& Bell, 1953) the sugars were detectable in the effluent as follows (mean of 5 experiments): xylose $315-440 \mathrm{ml}$., glucose $355-520 \mathrm{ml}$., rhamnose $505-650 \mathrm{ml}$; the corresponding figures for a B.D.H. activated charcoal-Celite column were: 126-194, 134-208, 208-272 ml. 
The value of this method lies in its use in conjunction with partition chromatography; it should be particularly useful for separating pairs of sugars, e.g. ribose-fucose, which have very similar $R_{F}$ values in aqueous butanol.

I am very grateful to Dr Whelan and his colleagues at the Lister Institute for information about the charcoal and their unpublished experiments. This work was done with the technical assistance of Miss A. M. Joss.

\section{REFERENCES}

Bacon, J. S. D. \& Bell, D. J. (1953). J. chem. Soc. p. 2528. Hough, L., Jones, J. K. N. \& Wadman, W. H. (1949). J. chem. Soc. p. 2511.

Hughes, R. C. \& Whelan, W. J. (1958). Chem. \& Ind. (in the Press).

Lemieux, R. U., Bishop, C. T. \& Pelletier, G. E. (1956). Canad. J. Chem. 34, 1365.

Whistler, R. L. \& Durso, D. F. (1950). J. Amer. chem. Soc. 72, 677.

Conductivity and pH Measurements in Protein Electrophoresis Experiments. By M. A. Rosemeyer, E. M. Shooter and E. R. SkInNer. (Physics Department, Birkbeck College and Department of Biochemistry, University College London)

The spread of a moving protein boundary in electrophoresis is controlled by the conductivity and $\mathrm{pH}$ changes across this boundary (Longsworth, 1947) and the magnitude and direction of these phenomena are dependent on the relative equivalent concentrations of buffer salt and protein, and on buffer ionization and ion mobility. The effect of these variables on the spread and therefore resolu. tion of the boundaries of two closely related proteins, haemoglobins $A$ and $S$, has already been examined (Shooter \& Skinner, 1955).

Further information has now been obtained by determining the conductivities and $\mathrm{pH}$ 's of the phases separating in the ascending limb during the analysis of these proteins. Four different systems, phosphate and cacodylate buffers below the isoelectric point of the haemoglobins and barbiturate and tris(hydroxymethyl)aminomethane buffers above the isoelectric point, all at constant ionic strength and equivalent concentration of protein, have been examined. In all systems the experimentally determined sharpening ratio (Dismukes \& Alberty, 1954) correlated well with the actual spread of the moving boundaries. Where the ratio was high, as in phosphate buffer, good resolution was obtained and conversely, where the ratio was close to unity as in barbiturate buffer, practically no resolution was achieved.

Some unusual features appear in these experiments. The relative magnitude of the conductivity changes in the various buffers do not agree with the Dole (1945) theory. Furthermore, although the $\mathrm{pH}$ changes across the protein boundaries are in the predicted direction they are, with the possible exception of the experiment in tris buffer, greater in magnitude. A noticeable characteristic of three of these experiments is the large $\mathrm{pH}$ difference between the dialysed protein and buffer solutions. Similar results have been found in other protein systems, for example, ribonuclease in phosphate or bovine serum albumin in chloride solutions. It is significant, however, that for ovalbumin in acetate buffer, where the electrophoretic behaviour can be accurately predicted by the Dole theory, only small changes of $\mathrm{pH}$ occur on dialysis.

\section{REFERENCES}

Dismukes, E. B. \& Alberty, R. A. (1954). J. Amer. chem. Soc. 76, 191.

Dole, V. P. (1945). J. Amer. chem. Soc. 67, 1119.

Longsworth, L. G. (1947). J. phys. Colloid Chem. 51, 171. Shooter, E. M. \& Skinner, E. R. (1955). Biochem. J. 60, xxviii.

The Electrophoretic Analysis of Human Haemoglobins. By E. M. SHootrer, E. R. SkINNER and J. C. WHITE. (Department of Biochemistry, University College London, and Department of Pathology (Haematology), Postgraduate Medical School of London)

One of the buffers (phosphate, pH 6.40, ionic strength 0.04) previously advocated for the analysis of haemoglobins (Shooter \& Skinner, 1955) has now been extensively used in the analysis of a variety of haemoglobins. This work illustrates the advantages and disadvantages of using a buffer which causes sharpening of ascending moving boundaries in systems of closely related proteins.
Complete resolution of haemoglobin boundaries is obtained for heterozygous $\mathrm{C}, \mathrm{E}, \mathrm{S}, \mathrm{G}, \mathrm{J}$ and $\mathrm{H}$ haemoglobins and sickle cell-haemoglobin $\mathrm{C}$ disease. A necessary consequence of achieving resolution of haemoglobins with very close mobilities, e.g. $S$ and $C$, is the accentuation of the apparent proportion of the leading component and diminution of the slower component (Hoch, 1950). 
Thus, in the analysis of normal adult haemolysates, haemoglobin- $\mathrm{A}_{2}$ (Kunkel \& Wallenius, 1955), which migrates faster than haemoglobin-A, is readily observed, but the slower minor component is more difficult to detect. The elevation of haemoglobin- $\mathrm{A}_{2}$ in thalassaemia minor, and the appearance of two components in approximately the haemoglobin- $\mathrm{A}_{2}$ position in stored concentrated oxyhaemoglobin solutions, can also be demonstrated when these are analysed as carboxyhaemoglobin.

Identification by absolute mobilities is possible only with homozygotes since the boundaries due to the two haemoglobins in heterozygotes do not separate in the descending limb. Apparent mobilities from the sharper ascending boundaries can, however, be determined with accuracy. Furthermore, the differences in apparent mobility of the various haemoglobins can be increased by suitable choice of buffer, phosphate giving a greater difference than cacodylate (Itano, 1953).

In mixtures, however, the apparent mobility of any haemoglobin depends both on the type of accompanying haemoglobin and on their relative proportions, and thus identification by mobility differences is often not possible. For this reason, identification of haemoglobins of heterozygotes is best accomplished by addition of a known haemoglobin, and the requisite analysis of three-component mixtures, for example $\mathrm{A}+\mathrm{S}+\mathrm{E}, \mathrm{A}+\mathrm{E}+\mathrm{C}$ and $\mathrm{A}+\mathrm{S}+\mathrm{C}$, can be achieved in phosphate buffer. Such experiments lead to a relative order of mobilities $\mathrm{C}>\mathrm{E}>\mathrm{S}>\mathrm{G}>\mathrm{A}>\mathrm{J}$, with $\mathrm{H}$ migrating in the opposite direction.

One of us (E.R.S.) is indebted to the Colonial Medical Research Council for a research grant. Part of the apparatus used in this research was purchased with a grant from the Central Research Fund. We wish to thank Drs N. A. Barnicot, J. Garlick, E. Huehns and H. Lehmann for samples of abnormal haemoglobins.

\section{REFERENCES}

Hoch, H. (1950). Biochem. J. 46, 199.

Itano, H. A. (1953). Science, 117, 89.

Kunkel, H. G. \& Wallenius, G. (1955). Science, 122, 288.

Shooter, E. M. \& Skinner, E. R. (1955). Biochem. J. 60, xxviii.

\section{An Electrophoretic Investigation of Ribonuclease. By M. A. Rosemeyer and E. M. SHooter. (Physics Department, Birkbeck College and Department of Biochemistry, University College London)}

There is evidence from chromatographic and zone electrophoresis techniques that ribonuclease contains several protein components, two of which are known as ribonuclease $\mathbf{A}$ and $\mathbf{B}$ (Hirs, Moore \& Stein, 1953; Raacke, 1956; Hakim, 1956). This heterogeneity has not been detected in moving boundary electrophoresis experiments. However, it is possible to show that suitable selection of buffer conditions permits the separation of four components by this technique. These experiments fall into two groups; one in which boundary anomalies are suppressed, and a second where these anomalies are accentuated.

The first condition, for example in tris(hydroxymethyl)aminomethane buffers at $\mathrm{pH}$ values near the isoelectric point of ribonuclease, at an ionic strength of $0 \cdot 1$, is favourable for the separation of a slow minor component. The second condition holds in sodium acetate buffers near $\mathrm{pH} 5$, ionic strength of 0.06 , and gives good resolution of a fast minor component. Experiments at intermediate conditions, for example, in cacodylate buffers at $\mathrm{pH} 6$, ionic strength 0.06 , show the presence of a fourth component after electrophoresis for $48 \mathrm{hr}$. at a field strength of $5.5 \mathrm{v} / \mathrm{cm}$.
Mobilities calculated from both limbs of the Tiselius cell show a good correlation with each other, and are also approximately related to the titration data (Tanford \& Hauenstein, 1956). However, this is not true in phosphate buffers (Crestfield \& Allen, 1954), which indicates interaction between these ions and the protein.

The difference between the mobility of ribonuclease in phosphate and in other buffers reaches a maximum at $\mathrm{pH} 6 \cdot 5-7 \cdot 0$, at 0.06 ionic strength. This indicates that the phosphate-protein interaction is a maximum in this $\mathrm{pH}$ range, and suggests that there is a specific association between at least one histidine residue on the protein and these ions. However, the participation of other charged groups is also probable from the mobility differences found at higher $\mathrm{pH}$ 's.

The considerations are of importance for the action of ribonuclease as a phosphorylase (cf. Weil \& Seibles, 1955; Anfinsen \& Redfield, 1956). The nature of these interactions, and their quantitative aspects are being further investigated.

One of us (M.A.R.) would like to thank the Nuffield Foundation and the Department of Scientific and Industrial Research for financial support during this research. 


\section{REFERENCES}

Anfinsen, C. B. \& Redfield, R. R. (1956). Adv. Protein Chem. 11, 1.

Crestfield, A. M. \& Allen, F. W. (1954). J biol. Chem. 211, 363.

Hakim, A. A. (1956). Biochim. biophys. Acta, 20, 581.
Hirs, C. H. W., Moore, S. \& Stein, W. H. (1953). J. biol. Chem. 200, 493.

Raacke, I. D. (1956). Arch. Biochem. Biophys. 62, 184.

Tanford, C. \& Hauenstein, J. D. (1956). J. Amer. chem. Soc. 78, 5287.

Weil, L. \& Seibles, T. S. (1955). Arch. Biochem. Biophys. 54, 368 .

The Fermentation of Lactate and Acrylate by Cell-Free Extracts of the Rumen Organism LG 1 . By J. N. LADD and D. J. Walker (introduced by S. R. ElsDen). (A.R.C. Unit for Microbiology, Department of Microbiology, Sheffield University)

Cell-free extracts of the rumen organism LC1 (Elsden, Volcani, Gilchrist \& Lewis, 1956) have been prepared which ferment lactate and acrylate to $\mathrm{H}_{2}, \mathrm{CO}_{2}$, acetate and propionate, and pyruvate to $\mathrm{H}_{2}, \mathrm{CO}_{2}$ and acetate. The rate of $\mathrm{H}_{2}$ production is a convenient measure of the rate of fermentation of these substrates. Freshly prepared extracts fermented both lactate and acrylate rapidly. Extracts which had been dialysed for 4-6 hr. at $4^{\circ}$ no longer fermented these two substrates, although they still attacked pyruvate rapidly. The activity of these dialysed extracts was restored by the addition of catalytic amounts $(0.8 \mu \mathrm{moles} / \mathrm{ml}$.) of either pyruvate, acetyl-phosphate, ATP or ADP; AMP was inactive. Further, lactate catalysed the fermentation of acrylate, and acrylate catalysed the fermentation of lactate.

Extracts which had been dialysed overnight at $4^{\circ}$ were not reactivated by catalytic amounts of any of the above compounds. However, when catalytic amounts of acrylate were added to substrate amounts of lactate, $\mathrm{H}_{2}$, approximately equivalent to the amount of acrylate added, was evolved. A similar effect was observed when catalytic amounts of lactate were incubated with excess acrylate.

There was no loss of activity when extracts were centrifuged for $1 \mathrm{hr}$. at $144000 \mathrm{~g}$ at $2^{\circ}$. The fermentation of lactate by such centrifuged extracts was completely inhibited by $2 \cdot 10^{-5} \mathrm{M}$-2:4-dinitrophenol, $2 \cdot 10^{-3} \mathrm{M}$-azide, $10^{-4} \mathrm{M}$-hydroxylamine and $2 \cdot 10^{-3} \mathrm{M}$-arsenate. In parallel experiments acrylate fermentation was completely inhibited by $10^{-5} \mathrm{M}$ 2:4-dinitrophenol, $2 \cdot 10^{-4} \mathrm{M}$-azide, $2 \cdot 10^{-5} \mathrm{M}$-hydroxylamine and $10^{-2} \mathrm{M}$-arsenate.

When $\left[2 \cdot{ }^{14} \mathrm{C}\right]$ lactate was added to an extract and the fermentation stopped by the addition of hydroxylamine, chromatography of the reaction mixture followed by radioautography showed radioactive areas corresponding to acetyl, propionyl and lactyl hydroxamates; in addition, spots appeared on the radioautogram which were not hydroxamates and which have not been identified.

This work was supported by the Rockefeller Foundation.

\section{REFERENCE}

Elsden, S. R., Volcani, B. E., Gilchrist, F. M. C. \& Lewis, D. (1956). J. Bact. 72, 681.

\section{A Coupled Oxidation-Reduction Reaction Involving Lactate and Acrylate. By D. J. WALKER and J. N. LAdD (introduced by S. R. ElSDEN). (A.R.C. Unit for Microbiology, Department of Microbiology, University of Sheffield)}

Ladd \& Walker (1958) reported that overnight dialysis of LC 1 extracts resulted in the complete loss of ability to ferment either lactate or acrylate, whilst hydrogen production from pyruvate remained relatively unimpared. However, when such extracts were incubated in phosphate buffer with lactate and acrylate together, hydrogen was produced; the amount was approximately equal to the amount of the substrate which was limiting. Thus, when 5,10 or $20 \mu$ moles of acrylate were incubated with an excess of lactate, 4.0, 7.8 and $15.5 \mu$ moles of $\mathrm{H}_{2}$ were produced. When the same amounts of lactate were incubated with excess acrylate, $4 \cdot 4,9 \cdot 1$ and $17 \cdot 6 \mu$ moles of $H_{2}$ were formed.
These observations suggest that extracts catalyse a reaction between lactate and acrylate yielding pyruvate and propionate; the pyruvate so formed is then broken down to $\mathrm{H}_{2}, \mathrm{CO}_{2}$ and acetate. This hypothesis requires that the pyruvate is derived from lactate and the propionate from acrylate. This was tested by incubating an excess of $\left[2-{ }^{14} \mathrm{C}\right]-$ lactate with acrylate and examining the products. A carbon and hydrogen balance showed that equal amounts of $\mathrm{H}_{2}, \mathrm{CO}_{2}$, propionate and acetate were formed. The isotope was located almost entirely in the acetate, which had a specific activity similar to that of the lactate added. In parallel experiments in which imidazole buffer was used instead of phosphate buffer, a large amount of 
pyruvate accumulated which had the same specific activity as the lactate. In neither case was propionate significantly labelled.

This reaction was also demonstrated in nondialysed extracts when the following inhibitors of lactate and acrylate fermentation were present: $10^{-4} \mathrm{M}$-hydroxylamine, $2 \times 10^{-3} \mathrm{M}$-azide or $10^{-4} \mathrm{M}$ dinitrophenol.

The results given in both this and the previous communication suggest that the fermentation of both lactate and acrylate can be explained by the following equations :

$$
\begin{array}{ll}
\text { lactate } & \rightleftharpoons \text { acrylate } \\
\text { lactate }+ \text { acrylate } & \rightarrow \text { pyruvate }+ \text { propionate } \\
\text { pyruvate }+\mathrm{H}_{2} \mathrm{O} & \rightarrow \text { acetate }+\mathrm{H}_{2}+\mathrm{CO}_{2}
\end{array}
$$

The mechanism of reaction (1) is unknown and would seem likely to be complex. The products of fermentation can be accounted for by reactions (2) and (3), which, so far as is known, proceed without activation. Thus, it is reasonable to suppose that reaction (1) is the step which requires activated substrates. Further, because neither reaction (2) nor (3) are inhibited by hydroxylamine, azide or dinitrophenol, these compounds must inhibit some step in reaction ( 1 ).

This work was supported by the Rockefeller Foundation.

\section{REFERENCE}

Ladd, J. N. \& Walker, D. J. (1958). Preceding abstract.

Changes in Retinal Glycolysis Co-incident with the Opening of the Eye in the Rat. By C. N. Graymore (introduced by M. KerLy). (Department of Pathology, Institute of Ophthalmology, University of London)

The anaerobic glycolytic activity of the rat retina doubles during the 10th-13th day after birth (Graymore, 1958a), this surge in activity coinciding with the period in which the eyes open. In the rats used in this investigation the eyes opened on the 12th-13th day of life, and it was suggested that the observed increase may be light-dependent, possibly as a response to an increased energy demand co-incident with the appearance of electrical activity in the retina.

The present communication describes experiments designed to test this hypothesis. Three litters of albino rats, of the same strain as those used in the above experiments, were kept in total darkness between the 10th and 15th days of life. At the end of this period they were sacrificed by decapitation in the dark and their retinae removed in the light by the procedure reported previously (Graymore, 1958b). The rate of anaerobic glycolysis was determined manometrically in a KrebsRinger bicarbonate buffer gassed with $95 \% \mathrm{~N}_{2}-$
$5 \% \mathrm{CO}_{2}$, and the final result expressed on a protein basis. It was found that these animals showed the same increase in activity during their confinement as those bred normally in the light, and it would appear therefore that the increased activity is independent of light stimulation, possibly being a reflection of the state of histological development of the retina.

Furthermore, one exceptional litter was obtained in which only three of the animals had opened their eyes by the 14th day of life. The eyes of the remainder were still firmly closed. Examination showed that the animals which had their eyes closed exhibited the same high retinal glycolytic rate as those in which the eyes were open. This confirms the above observations.

\section{REFERENCES}

Graymore, C. N. (1958a). Brit. J. Ophthal. (in the Press). Graymore, C. N. (1958b). Brit. J. Ophthal. (in the Press).

The Effects of Thiopentone, Azacyclonol (Frenquel) and Reserpine on Rat Brain Phospholipid Metabolism in vivo. By G. B. Ansell and AnNa Morgan. (M.R.C. Neuropsychiatric Research Unit, Whitchurch Hospital, Cardiff)

It is known that the rate of phospholipid synthesis in brain tissue is depressed in certain conditions, e.g. insulin hypoglycaemia and thiopentone anaesthesia (Dawson \& Richter, 1950; Ansell \& Dohmen, 1957). These studies have now been extended to show the effect of certain compounds on the turnover of two known phospholipid precursors, namely phosphorylethanolamine and phosphorylcholine.

The phospholipid turnover was measured by the uptake of $\left[{ }^{32} \mathrm{P}\right]$ orthophosphate into individual phospholipid fractions after a $3 \mathrm{hr}$. isotope exchange period, using the method of Dawson (1954). For the measurement of the uptake of ${ }^{32} \mathrm{P}$ 
into the free phosphate esters of the tissue extracts, the following procedure was used. Trichloroacetic acid extracts of brain tissue were freed from nucleotides by adsorption onto charcoal. Most of the inorganic phosphate was then removed with barium hydroxide and the barium salts of the remaining phosphate esters were converted to ammonium salts with Amberlite IR-120 $\left(\mathrm{NH}_{4}{ }^{+}\right)$ (cf. Heald, 1956). Phosphorylethanolamine and phosphorylcholine were then separated by paper chromatography.

The uptake of ${ }^{32} \mathrm{P}$ into rat brain phosphorylcholine after a $3 \mathrm{hr}$. exchange period was approximately twice that into phosphorylethanolamine, which may be related to the fact that the synthesis of phosphatidyl choline in the brain proceeds more rapidly than that of the ethanolamine-containing phospholipids (Ansell \& Dohmen, 1957). Thiopentone anaesthesia had no significant effect on the synthesis of the precursor phosphorylethanolamine or phosphorylcholine, whereas it decreased by $50 \%$ the incorporation of labelled phosphate into the phospholipids phosphatidyl ethanolamine and phosphatidyl choline. This indicates that thiopentone may affect steps in the synthetic chain other than the simple phosphorylation of lipid bases.
Magee, Berry \& Rossiter (1956) have observea an effect of azacyclonol on phospholipid labelling by ${ }^{32} \mathrm{P}$ in vitro. In our experiments doses of azacyclonol of the order of $70 \mathrm{mg} . / \mathrm{kg}$. body weight had no apparent effect on the metabolism of phospholipids, but larger doses (200-250 mg./kg. body weight) depressed the synthesis; no effect was, however, observed on the synthesis of phosphorylethanolamine and phosphorylcholine. Reserpine (5-10 mg./kg. body weight) had neither a depressant effect on synthesis of phospholipid nor on the synthesis of the two lipid bases studied. In these experiments the anaesthetic and tranquillizer drugs appear to act at different points in the synthetic chain.

The assistance of Miss Anne Phillips is gratefully acknowledged.

\section{REFERENCES}

Ansell, G. B. \& Dohmen, H. (1957). J. Neurochem. $2,1$. Dawson, R. M. C. (1954). Biochim. biophys. Acta, 14, 374.

Dawson, R. M. C. \& Richter, D. (1950). Proc. Roy. Soc. B, 137, 252.

Heald, P. J. (1956). Biochem. J. 63, 235.

Magee, W. L., Berry, J. P. \& Rossiter, R. J. (1956). Biochim. biophys. Acta, 21, 408.

The Production of Lipolytic Activity in the Girculation of the Hind Limb in Response to Heparin. By D. S. Robinson and P. M. HaRris. (Sir William Dunn School of Pathology, Oxford)

It has been shown that lipolytic activity can be demonstrated in the blood following the intravenous injection of heparin. No such activity can be demonstrated when heparin is added to blood in vitro. This suggests that some factor from the tissues may be necessary for the production of activity (Robinson \& French, 1957). In the present communication some experiments on the lipolytic activity which is induced in the circulation of the hind limb in response to the injection of heparin will be described.

Two series of experiments were performed. In the first heparin was injected into the femoral arteries of rabbits and serial blood samples were taken from their femoral veins from the time of injection. Lipolytic activity was present in the venous blood about 20 sec. after the injection of heparin into the artery. When Evans Blue dye was injected with the heparin, the dye and the lipolytic activity appeared in the same sample of venous blood. Lipolytic activity persisted in the venous blood for some time after the dye concentration had fallen to a low level. These experiments, together with others already reported (Robinson, Harris \& Ricketts, 1958), suggest that the lipase, or some substance essential for the lipase action, may be removed by the circulating heparin from the inner surface of the blood-vessel wall. The finding that lipolytic activity can be produced in the blood circulating through the hind limb suggests that this response to heparin may be a general characteristic of blood vessels.

In a second series of experiments the isolated hind-quarters of rats were perfused with heparin in plasma, in a solution of albumin, or in various mixtures of plasma and albumin solution. The lipolytic activity detectable in the perfusate fell as the proportion of plasma in the perfusing fluid was lowered. Plasma added to the perfusate before its lipolytic activity was determined did not raise that activity. These experiments suggest that the appearance of lipolytic activity in blood in response to heparin injection is dependent on the presence of some component of the plasma.

\section{REFERENCES}

Robinson, D. S. \& French, J. E. (1957). Quart. J. exp. Physiol. 42, 151.

Robinson, D. S., Harris, P. M. \& Ricketts, C. R. (1958). Biochem. J. (in the Press). 


\section{Effect of Cyanide on Succinic Dehydrogenase. By D. KEILIN and Tsoo E. KIna.* (Molteno Institute, University of Cambridge)}

It was shown by Tsou (1951) that the oxidation of succinate by heart-muscle preparation with methylene blue as hydrogen acceptor is abolished by prolonged incubation of the preparation with cyanide. While we confirmed this observation, we found that the activity of the same cyanidetreated preparation, when tested with phenazine methosulphate, was if anything higher than that of the untreated preparation. A similar result was obtained with soluble succinic dehydrogenase prepared by the method of Wang, Tsou \& Wang (1956) slightly modified by us (Keilin \& King, 1958). While succinic dehydrogenase reacts directly with phenazine (Kearney \& Singer, 1956), with methylene blue it reacts through some components of the respiratory chain (Slater, 1949). Since the oxidation of succinate by the heart-muscle preparation pre-incubated with cyanide showed no inhibition when tested with phenazine, while it showed a complete inhibition when tested with methylene blue, it suggested at first that cyanide reacted not with dehydrogenase but with another component of the respiratory chain. That this is not so can be demonstrated as follows: It was previously shown (Keilin \& King, 1958) that on bringing together soluble succinic dehydrogenase and a particulate heart-muscle preparation containing the cytochrome oxidase system, but devoid of succinic dehydrogenase, an active succinic oxidase system

* Senior Post-doctoral Fellow, National Science Foundation and Guggenheim Fellow. was obtained which catalysed the oxidation of succinate with either methylene blue or oxygen. However, such reconstitution of the succinic oxidase system could not be obtained by using soluble succinic dehydrogenase either previously incubated with cyanide or isolated from a cyanidetreated heart-muscle preparation. All this indicates that the cyanide inactivation of heart-muscle preparation in Tsou's experiments was due to its reaction with succinic dehydrogenase itself. The fact that the reaction of succinic dehydrogenase with cyanide is slow, complete, but irreversible, militates against its possible reaction with the iron which is supposed to form part of the enzyme. Moreover, since cyanide did not react with flavin it is conceivable that it reacted with the disulphide group of protein to give one sulphydryl and one thiocyanate group (Mauthner, 1912). Whether this -S-S- group is present independently of, or derived from, pre-existing -SH groups of succinic dehydrogenase remains open for further study.

\section{REFERENCES}

Kearney, E. B. \& Singer, T. O. (1956). J. biol. Chem. 219, 963.

Keilin, D. \& King, T. E. (1958). Nature, Lond. (in the Press). Mauthner, J. (1912). Hoppe-Seyl. Z. 78, 28.

Slater, E. C. (1949). Biochem. J. 45, 1.

Tsou, C. L. (1951). Biochem. J. 49, 512.

Wang, T. Y., Tsou, C. L. \& Wang, Y. L. (1956). Scientia Sinica, 5, 73.

The Proteolysis of Glucagon and other Peptides by the Rat Liver in vitro. By A. J. Kenny. (Department of Biochemistry, University of Cambridge)

Glucagon loses biological activity when incubated with homogenates of many tissues. The properties of the enzyme in homogenates of rabbit and rat livers have been previously reported (Kenny, 1956). The proteolysis of glucagon by the supernatant fraction of a rat liver homogenate has been studied by a technique requiring only small quantities of substrate. The incubation mixtures were subjected to paper chromatography with 2-butanol-acetic acid (Light \& Simpson, 1956) and the proteolysis of glucagon revealed by the ninhydrin reaction.

The proteolytic enzyme was localized in the supernatant fraction of the rat liver homogenate. The $\mathrm{pH}$ optimum was about $7 \cdot 5$. The enzyme was strongly inhibited by $p$-chloromercuribenzoate and other inhibitors of thiol enzymes. The presence of insulin and corticotropin also inhibited the pro- teolysis of glucagon. In these respects the proteolytic enzyme was similar to the enzyme which causes biological inactivation. In addition, proteolysis of glucagon was partially inhibited by high concentrations of ethylenediaminetetra-acetic acid, tolbutamide, carbutamide and indole-3-acetic acid. Insulin was not hydrolysed under the same conditions as glucagon, although fractions $A$ and $B$ from oxidized insulin (Sanger, 1949) were attacked.

The products resulting from the incubation of glucagon with the supernatant fraction from liver homogenate were fractionated by paper chromatography and paper electrophoresis. Free amino acids occurred in the digests. No small peptides were found among the products at any time during incubation. Each of the 15 amino acids occurring in glucagon (Bromer, Sinn \& Behrens, 1957) were identified as products of hydrolysis. In similar 
experiments with fraction A, glycine, isoleucine, valine, glutamine and glutamic acid were identified, together with smaller amounts of cysteic acid, alanine and serine. These amino acids occur at the $\mathrm{N}$-terminal sequence of fraction $\mathrm{A}$ of beef insulin (Sanger \& Thompson, 1953) and the results strongly suggest that an aminopeptidase was responsible. Results with fraction $B$ as a substrate were less conclusive but also consistent with the action of an aminopeptidase. The additional action of a carboxypeptidase could not entirely be ruled out with these substrates, since fractions $A$ and $B$ each contain residues (cysteic acid and proline respectively) near the $C$-termini which might inhibit the progress of hydrolysis by a carboxy- peptidase. However, the work of Rademaker \& Soons (1957) indicates that carboxypeptidase is absent from the supernatant fraction of a rat liver homogenate.

\section{REFERENCES}

Bromer, W. W., Sinn, L. G. \& Behrens, O. K. (1957). J. Amer. chem. Soc. 79, 2807.

Kenny, A. J. (1956). Amer. J. Physiol. 186, 419.

Light, A. \& Simpson, M. V. (1956). Biochim. biophys. Acta, 20, 251.

Rademaker, W. \& Soons, J. B. J. (1957). Biochim. biophys. Acta, 24, 451.

Sanger, F. (1949). Biochem. J. 44, 126.

Sanger, F. \& Thompson, F. O. P. (1953). Biochem. J. 53, 366.

Acetate Utilization in the Sheep. By E. F. Annison and D. B. Lindsay. (A.R.C. Institute of Animal Physiology, Babraham, Cambridge)

Acetate is recognized to be an important source of energy to ruminants. In these animals dietary carbohydrates are largely fermented to volatile fatty acids in the rumen, and acetic acid usually accounts for $60-70 \%$ of the acids present.

The utilization of acetate in the sheep has been investigated using $\left[1{ }^{14} \mathrm{C}\right]$ acetate and a constant infusion technique similar to that used by Steel, Wall, de Bodo \& Altszuler (1956) for glucose. Labelled acetate was infused at a constant rate until the specific activities of plasma acetate and respired $\mathrm{CO}_{2}$ were constant. The quantity of carrier acetate infused was insufficient to affect the circulating levels of acetate. Sheep fasted for $24 \mathrm{hr}$. were employed to minimize $\mathrm{CO}_{2}$ production in the rumen, and to eliminate rapid changes in ruminal acetate production which occur after feeding. The relative contributions of respiratory $\mathrm{CO}_{2}$ and ruminal $\mathrm{CO}_{2}$ to the total $\mathrm{CO}_{2}$ production were checked by using a face mask for total $\mathrm{CO}_{2}$ collection, and tracheal incubation which allowed only respiratory $\mathrm{CO}_{2}$ to be collected.

Preliminary results indicated that at plasma concentrations of $0.4-0.5 \mathrm{~m}-\mathrm{mole} / \mathrm{l}$. acetate utilization rates were $1 \cdot 4-2 \cdot 1 \mathrm{~m}-\mathrm{moles} / \mathrm{hr} . / \mathrm{kg}$. body wt. Utilization rates do not distinguish between acetate immediately oxidized and that used for synthesis. The ratio of the specific activities of circulating acetate and respired $\mathrm{CO}_{2}$ under equilibrium conditions, showed that about $25 \%$ of the $\mathrm{CO}_{2}$ was derived from acetate. Measurement of total $\mathrm{CO}_{2}$ production allowed the percentage of the acetate utilized which appeared as $\mathrm{CO}_{2}$ to be calculated, and values of $45-50 \%$ were obtained.

In single injection experiments using $100 \mu \mathrm{c}$ of $\left[1-{ }^{14} \mathrm{C}\right]$ acetate in fasting sheep the labelled material rapidly disappeared from the circulation with a half-life of $3 \cdot 5-4 \mathrm{~min}$. Respired $\mathrm{CO}_{2}$ reached maximum specific activity after $12 \mathrm{~min}$. and declined to half this value in about $2 \mathrm{hr}$. Of the total $\mathrm{CO}_{2}$ expired in $24 \mathrm{hr}$. after injection, about $50 \%$ appeared within the first $2 \mathrm{hr}$.

Further experiments are in progress to investigate acetate utilization rates at enhanced concentrations of acetate. The constant infusion method is particularly suited to this purpose since the plasma concentrations can be adjusted to any desired level. Similarly, the influence of raised blood levels of other metabolites, such as glucose can be studied.

\section{REFERENCE}

Steel, R., Wall, J. S., de Bodo, R. C. \& Altszuler, N. (1956). Amer. J. Physiol. 187, 15. 


\section{DEMONSTRATIONS}

The Purification of Proteins using Zone Electrophoresis on Plastic Sponge. By E. D. WIILs. (Department of Biochemistry, The Medical College of St Bartholomew's Hospital, London, E.C. 1)

A Micro-Reaction Calorimeter. By J. H. Ashby, S. P. Datta and J. J. Martin. (Department of Biochemistry, University College, London, W.C. 1)

Quantification in Agar Gel Diffusion Plates. By J. G. Fennberg. (Bencard Allergy Research Unit, Beecham Research Laboratories, Betchworth, Surrey) 